\title{
Izolacja więzienna jako doświadczenie egzystencjalne w literaturze polskiego baroku. Wybrane przykłady
}

\section{Marcin Pliszka}

ORCID: 0000-0002-0723-3320

(Uniwersytet Przyrodniczo-Humanistyczny w Siedlcach)

W jednym z rozdziałów Prób Michel de Montaigne kreślił znamienne słowa o wolności i swobodzie przemieszczania się:

\Nie przestąiłem progu żadnego więzienia, bodaj dla przyjrzenia się; samo wyobrażenie czyni mi jego widok, nawet z zewnątrz, odpychającym. Mam takie łaknienie wolności, iż gdyby mi ktoś zabronił przystępu do jakiegoś zakątka Indiów, żyłbym poniekąd przez to mniej swobodnie. [...] Jakże trudno by mi ścierpieć los, w którym widzę tylu ludzi, pozbawionych prawa odwiedzania stołecznych miast i dworów i użytku gościńców publicznych, za to, iż stawali sztorcem przeciw prawu! Gdyby te prawa, którym służę, zagroziły mi bodaj końcem palca, odszedłbym stąd bezzwłocznie szukać innych, mniejsza o to, gdzie ${ }^{\mathrm{I}}$.

W ceniącym sobie nad wszystko wolność Montaigne’u już myśl o zniewoleniu wywoływała irytację i przygnębienie. Ale francuski myśliciel szedł w swoim poczuciu wolności dalej, bo nawet wyobrażenie jakiegoś zakazu sprawiało, że czuł silny niepokój (plus mal à mon aise) ograniczający stan pełnej niezależności. Hipotetyczna dyrektywa nieodwiedzania jakiegoś zakątka Indii (do którego raczej

1 M. de Montaigne, Próby, tłum. T. Żeleński (Boy), oprac. Z. Gierczyński, t. 3, Warszawa 1985, s. 286-287. 
się nie wybierał) wywołała poczucie życia w jakiejś izolacji na poziomie mentalnym czy świadomościowym. Już nie tylko fizyczne, cielesne osadzenie i odizolowanie od świata napawa go przerażeniem, lecz także fakt jakiegokolwiek zakazu i ograniczenia swobody. W mniejszym stopniu, jak się zdaje, zajmują autora Prób kary stricte cielesne, które, co ukazuje Michel Foucault, znacznie ograniczono dopiero w XVIII wieku na rzecz „tortur bardziej wyciszonych” ${ }^{2}$. Choć izolacja też może być zaliczana do kar cielesnych, to jednak, zastrzega dalej Foucault, „stosunek kara - ciało nie jest tu tożsamy z tym, czym był w przypadku kaźni”’ Ograniczenie swobód oznacza dla Montaigne’a najwyższy stopień upośledzenia egzystencji opartej na niezależnej, fizycznej możliwości przemieszczania się. Tak w sferze duchowej (świadomość możliwości), jak i oczywiście cielesnej.

Karanie człowieka przez izolację, osadzenie w więzieniu, banicję, wygnanie czy inne formy fizycznego zniewolenia ${ }^{4}$ zawsze miało na celu ograniczenie jakichś praw, czyli było odbieraniem wolności, rozumianej jako prawo do czegoś, co jest dane wszystkim obywatelom społeczeństwa, w którym funkcjonują na równych zasadach. Kara izolacji przybierała różnego rodzaju formy, zależnie od możliwości podmiotu karzącego w sferze zarówno technicznej (zasoby budowli więziennych), jak i często finansowej (przetrzymywanie więźnia bywało kosztowne) ${ }^{5}$. W XVII wieku (i wcześniej) istniało wiele sposobów izolowania skazanego, który był karany za rozmaite przewinienia niezgodne $\mathrm{z}$ obowiązującym porządkiem prawnym i społecznym:

\section{1) Dawne prawo polskie, w zakresie szeroko rozumianych kar na wol- ności, przewidywało kilka znacznie różniących się między sobą form izolacji. Różnice te były konsekwencją podmiotów, wobec których mogły być stosowane, sposobu wykonywania, konsekwencji zastoso- wania - środek hańbiący czy też niehańbiący, a przede wszystkim miejsca jej wykonywania (mogły to być lochy, twierdze, zamki, klasz- tory, więzienia, wynajęte na ten cel karczmy, własny dom skazanego itp.). Do kar tego typu zaliczano karę wieży dolnej, karę wieży górnej,}

2 M. Foucault, Nadzorować i karać. Narodziny więzienia, tłum. T. Komendant, Warszawa 2019, s. 11.

3 Ibidem, s. 13.

4 W starożytnej Grecji funkcjonowała kara ostracyzmu, czyli pewnego rodzaju izolacji przestrzennej. Był to zakaz zbliżania się do określonego terytorium (najczęściej miasta). Ostracyzm różnił się od zwykłego wygnania i był łagodniejszy w skutkach, bowiem skazany zachowywał prawo do dysponowania majątkiem, zob. R. Flacelière, Życie codzienne w Grecji za czasów Peryklesa, tłum. Z. Bobowicz, J. Targalski, Warszawa 1985, s. 200.

5 Dość szczególowy opis sposobów karania i przetrzymywania skazanych w zamknięciu podaje Władysław Łoziński (Prawem i lewem. Obyczaje na czerwonej Rusi w pierwszej potowie XVII wieku, oprac. J. Tazbir, Warszawa 2005, rozdział: Niedostatki prawa). 
więzienie, dom poprawy, dom pracy, a także mające nieco odmienny charakter kary - klatki, kuny, kłody, gąsiory, biskupa i aresztu domowego ${ }^{6}$.

Do pozbawienia wolności dochodziło w wyniku konfliktu z obowiązującymi zasadami prawnymi czy z regułami współżycia społecznego (relacja pan-podwładny), lub też w wyniku dostania się do niewoli podczas działań wojennych, potyczek, bitew, co skutkowało osadzeniem pojmanych w szeroko pojętym więzieniu i w znacznym stopniu ograniczało ich prawa. W pierwszym przypadku prawo bywało świadomie łamane, a popełniający czyn $\mathrm{z}$ reguły zdawał sobie sprawę z grożących konsekwencji, w drugim zaś - okoliczności uwięzienia stanowiły najczęściej splot różnych wypadków losowych (nierzadko osadzeni jeńcy skarżyli się na nieprzychylny los i wyroki fortuny). Można mówić o systemowym karaniu, w jakiś sposób skodyfikowanym, a zatem zracjonalizowanym, choć pozbawienie wolności nie było wówczas karą sądową ${ }^{7}$, oraz o pozasystemowym przetrzymywaniu jeńców, którzy byli zdani na kaprysy i łaskę zwycięzców.

Użyte w tytule sformułowanie „izolacja więzienna” w kontekście siedemnastowiecznego systemu karania jest wieloaspektowe. Termin „więzienie” według słownika Lindego oznacza zarówno budowlę, w której przetrzymuje się więźniów, jak i na przykład narzędzie o nazwie „kłoda”, w którym zamyka się skazanego, izolując go na jakiś czas (raczej krótki) od społeczeństwa, co z trudem daje się objąć terminem „więzienie”, który rozumiemy dzisiaj instytucjonalnie. Na pewno bardziej „klasyczną” formą izolacji była kara tak zwanej wieży, podzielonej na dwa poziomy; uwięziony w dolnej części był niemal całkowicie odcięty od świata zewnętrznego, $\mathrm{w}$ fatalnych warunkach, w ciemności, wilgoci i zimnie odsiadywał wyrok (najczęściej za zabójstwo), ale już kara wieży górnej - stosowana dla lżejszych przestępstw okazywała się znacznie łagodniejsza ${ }^{8}$. Zdarzały się przypadki opuszczania miejsca izolacji i swobodnego przechadzania po mieście, a nawet biesiadowania w wieży9 Wróćmy jednak do niepokoju Montaigne’a i doświadczania życia w zamknięciu. Izolacja to przede wszystkim jakaś strata egzystencjalna krępująca niezbywalne prawo do stanowienia o sobie samych. Tytułową formułę odnoszę zatem do wszel-

6 T. Kalisz, Kara pozbawienia wolności na ziemiach polskich od XV do potowy XIX wieku, „Acta Universitatis Wratislaviensis. Przegląd Prawa i Administracji” 2020, t. 120, nr 2, s. 679-680. Warto zaznaczyć, że kara więzienia - jak zauważa Tomasz Kalisz - była stosowana dopiero pod koniec XVII w. (s. 680).

7 Ibidem.

8 Ibidem, s. 680-681.

9 W. Łoziński, Prawem i lewem..., s. 49. 
kich kar izolacji polegających na ograniczeniu swobodnego przemieszczania się i utracie podstawowych praw obywatelskich.

Warunki przetrzymywania więźniów bywały bardzo różne i często zmieniały się w zależności od miejsca, od dysponenta, czyli tego, który ustanawiał zasady przetrzymywania, od klimatu, uwarunkowań przestrzennych i architektonicznych. Jednak każda przymusowa izolacja, odseparowanie od rodziny, domu, ojczyzny, niewątpliwie stanowi traumatyczne doświadczenie egzystencjalne. Świadectwa tego typu przeżyć znajdziemy w różnych gatunkowo tekstach pisanych mową wiązaną i niewiązaną. Cały materiał egzemplifikacyjny, na którym opieram moje uwagi, składa się z relacji jeńców, to jest osób, które zostały uwięzione w wyniku działań wojennych lub konfliktów politycznych. Teksty te zostały napisane przez ludzi bezpośrednio doświadczających więziennej izolacji, zatem będzie to literatura dokumentu osobistego zdająca relację z obcej niewoli. Pod tym względem wiek XVII był czasem wyjątkowego niepokoju i rozlicznych konfliktów - z Rosją, Turcją, ze Szwedami - co było też szeroko komentowane, interpretowane i opowiadane w literaturze okolicznościowej. Duża część uczestników owych konfliktów dostawała się do niewoli, z czego chętnie zdawano relacje. Zresztą w tym czasie mamy wielką obfitość pamiętników, diariuszów, listów, w których znajdziemy dokładnie opisywane niedole obcego więzienia ${ }^{\mathrm{IO}}$.

W tym szkicu interesuje mnie kilka zagadnień związanych z człowiekiem uwięzionym, czyli, mówiąc wprost, człowiekiem poddanym różnego rodzaju przymusowi. Brak kontroli nad własnymi decyzjami w kwestii elementarnych potrzeb, takich jak jakość i ilość pożywienia czy wybór miejsca przebywania, stanowi podstawową udrękę osadzonego. Sytuacja zniewolenia, odebrania podstawowych praw, powoduje, że nad byciem w świecie traci się kontrolę albo jest ona jedynie cząstkowa, a w znacznej mierze zależna od kaprysów oprawcy - dysponenta przywilejów.

Jednym z największych problemów izolacji jenieckiej były niedostatki żywieniowe, a ściśle - powszechnie odczuwany głód. Kwestię tę podnoszono wielokrotnie i w wielu relacjach, można nawet pokusić się o stwierdzenie, że głód był wspólnym problemem wszystkich więźniów, którzy dostali się do niewoli jenieckiej. Ten motyw wciąż powraca w relacji Stanisława Niemojewskiego, a w zasadzie stanowi leitmotiv jego długiej i skrupulatnie prowadzonej narracji więziennej z niewoli

10 Niestety nie znalazłem relacji ludzi osadzonych np. w tzw. wieży dolnej. Rzecz w sumie zrozumiała, był to inny rodzaj uwięzienia, znacznie ograniczający swobodę i wyjątkowo dotkliwy. Poza udręką ciała i duszy takie doświadczenie nie wpisuje się w żaden paradygmat zdarzeń mogący dawać asumpt do pisania, jak miało to miejsce w przypadku relacji z wielkich wypraw polityczno-wojennych. Cierpienie pojedynczego osadzonego, jak się zdaje, pozostawało w tamtych czasach doświadczeniem cichym i samotniczym, dziś powiedzielibyśmy: niemedialnym, ale też nieartykułowalnym. To zagadnienie warte dalszych badań archiwalnych. 
rosyjskiej. Autor nieustannie wspomina o nękających więźniów brakach w pożywieniu:

\ Żeśmy więźniem trapieni niesłusznem, w którem głód i niedostatek nas dręczy, chowanie złe i ciężkie ${ }^{\mathrm{II}}$.

napiszem do hosudara, gdyż nas nad słuszność więzi, przynamniej głodem niech nie morzy, od którego już kilka z naszych umarło (SN, s. 215).

Również Abraham Rożniatowski wspomina o podobnych kłopotach:

》Die II., I2., I3., I4., I5., I6., I7., I8., I9., przez te dni nam żywności żadnej nie dawano, powiadając, że pieniędzy nie stało i samiśmy to widzieli, że posłańcy do Moskwy nie mogli przechodzić i z Moskwy nie słychać było nikogo, przeto musieliśmy sobie kupować, kto miał za $\mathrm{co}^{\mathrm{I} 2}$.

Poszliśmy spać, nie jedząc, a nazajutrz trzecią część nam ujęto wszelakiej żywności i picia. Co przedtem dosyć skąpo było, to potem w trzecie mniej ${ }^{\mathrm{I} 3}$.

To tylko wyimek z wielu skarg więźniów na cierpienie głodu, który w trudnych warunkach mógł prowadzić do śmierci osadzonego. Problem żywieniowy pogarszał się wraz z wydłużającym się okresem uwięzienia. $Z$ niedoborami pożywienia radzono sobie na różne sposoby, najczęściej pozyskiwano żywność na drodze handlu, ale i ta możliwość $z$ czasem się wyczerpywała $z$ powodu braku towaru na sprzedaż i pieniędzy ${ }^{\mathrm{I}}$.

11 S. Niemojewski, Diariusz drogi spisanej i różnych przypadków pociesznych i żatosnych prowadzac córkę Jerzego Mniszka, Marynę, Dymitrowi Iwanowiczowi w roku 1606, wyd. R. Krzywy, Warszawa 2006, s. 149 (dalej bezpośrednio po cytacie podaję numer strony ze skrótem SN).

12 Cytuję diariusz Abrahama Rożniatowskiego z niewoli moskiewskiej, który został wydany jako pamiętnik Dyamentowskiego przez Aleksandra Hirschberga: Polska a Moskwa w pierwszej potowie wieku XVII. Zbiór materiatów do historii stosunków polsko-rosyjskich za Zygmunta III, wyd. A. Hirschberg, Lwów 1901, s. 85. Zob. też R. Krzywy, Wstęp, w: A. Rożniatowski, Utwory okolicznościowe, oprac. R. Krzywy, Warszawa 2012.

13 Polska a Moskwa w pierwszej potowie wieku XVII..., s. 86.

14 Trzeba zaznaczyć, że sposób traktowania więźnia był zależny od jego pochodzenia i stanu, znacznie lepiej traktowano wysoko postawionych urzędników, wysokich rangą żołnierzy czy też przedstawicieli władzy. Zob. M. Barłowska, Michała Leona Obuchowicza teksty z moskiewskiej niewoli, „Śląskie Studia Polonistyczne" 2017, nr 2 (10), s. 31-32. 
\Die I8., I9. znowu nam jeść ani pić nie dano. Die 20. tylko piwa a gorzałki dali, ale się pić na czczo nie chciało. Die 21., 22. przecie żywności żadnej nie dano. Barzo się nam te przymorki przykrzyły, a zwłaszcza tym, którzy już resztem gonili. Pieniędzy nie było nie tylko u chudszych $[\ldots]^{15}$.

Bywało także, co odnotowuje Niemojewski, że uwięzieni otrzymywali zadośćuczynienie za brak posiłku w postaci środków płatniczych, za które mogli pozyskać żywność (SN, s. 216). Ale też z reguły, „gdy niewola przycisnęła, musieliśmy brać, co dano" (SN, s. 204). Jak widać, dostęp do pożywienia wiązał się najczęściej z nieunormowanymi racjami i przypadkowymi dostawami, zależnymi od kaprysu i woli strażników. W podobnym tonie o niedostatkach żywności donosi Adam Kamieński-Dłużyk:

\section{\Mnie oddano do Andrzeja Onofrejowicza, i ze mną pięcioro czeladzi spod różnych chorągwi. Tameśmy siedzieli niedziel 9, dość w nędzy i głodzie, ale jednak mieli na nas respekt mieszczanie mohylewscy, co nas żywili, bobyśmy inaczej pomarli byli ${ }^{\mathrm{T}}$.}

$Z$ powodu częstych zmian miejsca przetrzymywania osadzonych, los więźnia bywał bardzo zmienny, dotyczyło to także dostępności pożywienia, bowiem w różnych zakątkach geograficznych jedzenie było dostępne w różnym stopniu, nawet dla ludności tubylczej. Jedno z plemion syberyjskich częstowało jeńców rybami, których były nieprzebrane ilości („i sami nam dawali jako niewolnikom”) ${ }^{17}$, ale los bywał odmienny, w innej przestrzeni geograficznej pożywienia brakowało, przynajmniej dla jeńców: „Odpocząwszy sobie, szliśmy potym puszczą mil 25 do Jenisiejska; tak w nędzy wielkiej trwaliśmy, bo ani kupić, ani na sobie nieść nie mogliśmy”. Z kolei w Jenisejsku pożywienia było pod dostatkiem: „Ryb sroga moc; ptactwa i zwierza omal”8. W dalszej drodze jeńcy znowu cierpieli z powodu niedostatków pożywienia: „Staliśmy na jednym miejscu z tydzień, na sobie przynosząc rzeczy wszystkie z łodzi, nie żal by, gdyby swoje, ale carskie i przystawów. Tameśmy znowu zażywali biedy i głodu przy robocie” ${ }^{\text {I9 }}$.

15 Polska a Moskwa w pierwszej potowie wieku XVII..., s. 95.

16 A. Kamieński-Dłużyk, Diariusz więzienia moskiewskiego, miast i miejsc, oprac. A. Kuczyński, B. Polewoj, Z.J. Wójcik, Wrocław 1997, s. 13.

17 Ibidem, s. 26.

18 Ibidem, s. 27.

19 Ibidem, s. 30. 
Dieta więźnia w drodze bywała nieprzewidywalna. Adam Kamieński pozostawił dość osobliwe świadectwo uwięzienia, bowiem dla autora Diariusza więzienia moskiewskiego doświadczenie niewoli to przede wszystkim długa tułaczka po syberyjskich bezdrożach, przypominająca bardziej podróż turystyczną niż trud więzienny. Można metaforycznie mówić o jakiejś formie „izolacji nomadycznej”, odmiennej od formy osadzenia na dłużej w jednym miejscu.

Czasami dobrostan żywieniowy był zależny od osoby opiekuna-strażnika, czy niemal „właściciela”, czego doświadczył Stanisław Druszkiewicz w niewoli tatarsko-tureckiej ${ }^{20}$ :

\} \quad \text { Komu Pan Bóg śmierci nie dopuścił, to żywcem wzięto, żaden człowiek } tam ujść nie mógł i mnie wzięli do więzienia Tatarowie postrzelonego z łuku w łopatkę i łokcie posieczonego, w szyję z samopału. Dostałem się krymskiemu Tatarowi, [...]. Ubogi był sobak Tatar, bardzo mnie źle traktował i sam jeść nie miał co, nie trzymał mnie stąd w domu ledwo trzy niedziele. Przedał i mnie do Kiefy (Kaffy), miasta tureckiego nad morzem. Cnotliwy mnie Turczyn kupił, bardzo dobry człowiek [...]. Zaprawdę bardzom był niedrogi, bom też był nadkaleczony i szaleństwo zmyślałem. Ale jak mnie ten Turczyn kupił, tylko mojej było niewoli, bardzom się miał dobrze u niego i nie tak jako niewolnika, ale jako syna mnie swego traktował, i zarabiałem sobie $[\ldots]^{2 \mathrm{I}}$.

W niespokojnych czasach wojen dochodziło nierzadko do oblężenia, czyli do zamknięcia jakiejś grupy ludzi na obszarze ufortyfikowanej budowli, która stawała się wówczas specyficznym więzieniem. Taka izolacja przypominała charakterem uwięzienie skazańca w zamkniętej przestrzeni i następowała, kiedy obce wojska odcinały i uniemożliwiały jakikolwiek ruch poza mury oblężonego miasta, grodu czy zamku. Izolację od świata zewnętrznego w murach miasta można traktować jako formę uwięzienia, czyli tymczasowego zniewolenia ludności zamkniętej na niewielkiej przestrzeni i odciętej przede wszystkim od pożywienia (na co liczył „nieprzyjaciel fortelny, wiedząc o głodnych defektach zamkowych [...]”) $)^{22}$, co też

20 O niewoli tatarsko-tureckiej w literaturze obszernie pisała Renata Ryba (Literatura staropolska wobec zjawiska niewoli tatarsko-tureckiej. Studia i szkice, Katowice 2014; eadem, Motyw niewoli tatarsko-tureckiej w poezji poczatku XVII wieku: z perspektywy grzechu, „Napis” 2006, seria 12).

21 S.Z. Druszkiewicz, Pamiętniki 1648-1697, oprac. M. Wagner, Siedlce 2001, s. 88.

22 J. Budziło, Wojna moskierwska wzniecona i prowadzona z okazji fatszywych Dymitrów od 1603 do 1612 r[oku], oprac. J. Byliński, J. Długosz, Wrocław 1995, s. 168. Wybrane fragmenty dostępne w książce Mieczysława Wieliczki Jeniectwo wojenne Polaków w Rosji w latach 1503-1918 (Lublin 1998), a także w wyborze Hanny Malewskiej (Listy staropolskie z epoki Wazów, Warszawa 1959). 
wpisywało się w wojenną strategię oblężniczą polegającą na cierpliwym oczekiwaniu na wyczerpanie się zapasów. Makabryczny opis skrajnego głodu i nędznej egzystencji w obliczu niechybnej śmierci w zamknięciu oblężniczym dał w pamiętniku i listach chorąży mozyrski Józef Budziło. Nawet jeśli ten obraz jest w jakimś stopniu wykreowany, to skala cierpienia i perspektywa śmierci głodowej napawa przerażeniem. Przywołajmy dwa fragmenty:

\Zeszło na tym na zwykłej żywności, szukał łakomy a potrzebny żołądek nowej karmie, nowych traw i korzonków, których pod nieprzyjacielem z odwagą zdrowia swego zasięgać i onym często przepłacać przychodziło. Zeszło i na tych, rzucił się do niezwyczajnych jednak dla miłości ojczyzny i ceny cnoty pod ten czas smakowitych potraw, nie stało, psów nawet nie przypuszczano. Nastąpiła zatym rzadko słychana a przynajmniej skryta u nas prawie jawna samojedz $[\ldots]^{23}$.

Ciężko było z nieprzyjacielem bojować, ciężej z głodem walczyć, ciężej jeszcze z przyrodzeniem się biedzić, wprawiając się w niezwyczajne potrawy. [...] Smakowali jednak naszemu brzuchowi dla łaski [...], kotki, psy, szczury i łupieże, na potym z nich śmierdzące ścierwy takroczne, roboczywe a rozstoczone, skóry i rzemienie wszelakie z siodeł i łuków żyłowania, pergaminy, woski, trawy i zielska wszelakie, które jedno ziemia nosi, na ostatek, gdy to śnieg nielutościwie odjął, drzewo tarte, siano drobno siekane i co jedno podobieństwo do oszukania potrzebnego żołądka mieć mogło. [...] pan sługi, sługa pana, towarzysz towarzysz[a] nie był bezpieczen, jawnie ludzie na rzezią brano, zabijano, w sztuki rąbano, pieczono, warzono, na rożnach obracano $[\ldots]^{24}$.

Oczywistą konsekwencją niedożywienia były choroby prowadzące nierzadko do śmierci; pogarszający się stan zdrowia to stały element kaźni więziennej. W suplikach pisanych do władców osadzeni - charakterystyczny i częsty w relacjach podmiot zbiorowy - podkreślając wspólną niedolę, wielokrotnie skarżyli się na dolegliwości chorobowe. Był to kolejny czynnik wpływający na trudne warunki więziennej egzystencji psychofizycznej:

\Bez kapłana, bez doktora i wszelakiego ratunku, we złem zdrowiu.

23 J. Budziło, Wojna moskiewska..., s. 168.

24 Ibidem, s. 171. 
[...] Chorych sieła, zdrowszy strwożeni słuchając, rychło ich też co zaboli (SN, s. 203).

o takiej nędze, jaką cierpiem, już kilka między nami umarło, a więtsza połowica choruje (SN, s. 215-216).

O Narodzeniu Pańskiem choroba się między nami wzmogła, tak, że mało ich było, co by ich albo gorączka, albo bolenie gardła, albo zależenie w piersiach trapić nie miało, tylko że wżdy z łaski Bożej niedługo.W takiej mizeryi i nieszczęściu, z woli Pana Boga Wszechmocnego, zszedł rok 1606 w Jarosławiu ${ }^{25}$.

Niedożywieniu i chorobom towarzyszyły niedogodności związane z ograniczoną przestrzenią więzienną oraz srogie zimno, które doskwierało szczególnie osobom „nieprzyodziałym”, co w konsekwencji prowadziło do chorób i śmierci:

\A przychodzi nam jeszcze gorsza nędza z niedostatku izdeb, ile na tak zimna srogie, zwłaszcza ludziom nieprzyodziałem, bo na osób 60 i więcej izdeb trzy dano, gdzie ich trzecia część zmieścić się nie może, przez co więcej ich zimno cierpieć musi [...].Z takiej tedy nędzy już dwaj z czeladzi naszej umarło, drudzy w choroby wpadają i dalej, wie to Bóg, co będzie (SN, s. 154).

niech nie ma za złe, że tak na lada jakim i małym papierze odpisuję, tak więzienie ciasne u mnie [...] (list Jana Żółkiewskiego do Łukasza Miaskowskiego) ${ }^{26}$.

Nie zawsze przebywano w ciasnych izbach służących za więzienie. Niekiedy dawano jeńcom więcej swobody, choć były to sytuacje nieregularne, co odnotowuje Niemojewski w prośbie z supliki, by znowu pozwolić więźniom „gulać po polu bądź z sobakami, bądź też bez sobak" (SN, s. 154) lub kąpać się w rzece - co akurat dla jednego z towarzyszy skończyło się śmiercią: „Die I7.Jan Berezański, komornik Pana Wojewody, unurzał w rzece Kotorosi, kąpiąc się, czego nam za przystawami pozwolono było” ${ }^{27}$ - czy wreszcie spacerować po okolicy: „Żywności, acz niewiele,

25 Polska a Moskwa w pierwszej potowie wieku XVII..., s. 86.

26 Cyt. za: A.A. Witusik, Korespondencja jeńców cecorskich, „Rocznik Lubelski” 1987-1988, nr 29-30, s. 110. Korzystałem też z mikrofilmu rękopisu Biblioteki im. Raczyńskich w Poznaniu (sygn. 139) dostępnego w Bibliotece Narodowej pod sygnaturą mf 8919.

27 Polska a Moskwa w pierwszej potowie wieku XVII..., s. 105. 
jednak cokolwiek poprawili, wolności nam popuścili, tak na przechadzki, jako i do targu" 28 .

Niemniej nieliczne chwile swobody nie rekompensowały życia w „tesknicy” i nędzy. Abraham Rożniatowski opisuje żywot w niewoli jako serię różnorakich doświadczeń i przygód, wspomina też, nie bez satysfakcji, o bojaźni rosyjskich strzelców-strażników przed podpitymi Polakami, którzy w stanie upojenia byli skłonni do wszczynania kłótni i bijatyk. Życie w izolacji upływało między trwoga niepewnego losu i wyczekiwaniem lepszego jutra a awanturniczą dezynwolturą. Bycie jeńcem wojennym nie zawsze oznaczało zamknięcie w ciasnej izbie. Jeńcy to masa ludzi nadzorowana i ubezwłasnowolniona, ale również wymykająca się ścisłej kontroli. Egzystowanie w tak zorganizowanej izolacji było też dla więźnia uczestnictwem we wspólnocie ludzi, współtowarzyszy niedoli. Przy czym ograniczenia przestrzenne, stłoczenie osadzonych w niewielkich izbach, wydłużający się czas zniewolenia i pogarszające warunki pobytu prowadziły do napięć i sytuacji konfliktowych, niekiedy kończących się bójkami:

\section{1) Die Ir. stał się rozruch między nami samymi. Słudzy Pana Starosty krasnostawskiego porwali się na sługę starszego Pana Wojewody, tuż pod bokiem jego. Obraził się tem barzo Pan Wojewoda, kazał się zebrać wszytkiej czeladzi swej i sam zbieżał rozgniewany, ale oba- czywszy, że się Moskwa kupiła na dziw, potem się hamowali. Wiele inszych niesnasek i zwaśnienia, swarów, rosło między swymi ${ }^{29}$.}

Kłótnie, pisanie paszkwili, obmawianie, a ponadto „kosterstwa, pijaństwa obecne $[\ldots]$ ”, ,częste swary, niesnaski, zwady [...] pojedynki, bicia się i poranienia” przywołuje z kolei Niemojewski (SN, s. 218), aż do tragicznego w skutkach konfliktu zakończonego zabójstwem współwięźnia ${ }^{30}$. Wspólnotowa egzystencja więzienna przechodzi od fazy wspólnej sprawy (ten sam wróg i te same postulaty do wyegzekwowania) do zdziczenia obyczajów i moralnego rozprężenia. Przestrzeń wspólna rozumiana jako miejsce, a zarazem jednocząca dyrektywa walki z wrogiem, ulega stopniowemu rozkładowi na rzecz partykularnych - jak się zdaje - interesów.

Wszystkie wspomniane niedogodności i „utrapienia” niewoli: brak odpowiedniej ilości pożywienia, trudne warunki mieszkalne, ciasnota, zimno (szczególnie do-

28 Ibidem, s. 134.

29 Ibidem, s. 90.

30 Wypadki te doprowadziły do spisania artykułów, tj. zasad i praw regulujących stosunki między więźniami (SN, s. 226). 
tkliwe dla osób przetrzymywanych na terenach północnych, syberyjskich) ${ }^{3 \mathrm{I}}$ sprawiały, że pogarszał się stan duchowy więźniów, spadało morale, a nieustająca tęsknota do wolności, bliskich, domu wywoływała stany melancholijne: „Acz rozmaita nędza, najbardziej jednak więzienie melankoliją nam mnożeło, dręczeł też i niewczas z ciasnego mieszkania w miescu błotnistem, obecnej niepogody" (SN, s. 247).

Twardy los egzystencji więziennej skłaniał osadzonych do spojrzenia na swój los w perspektywie eschatologicznej. Myślenie o śmierci, potęgowane sukcesywnym wymieraniem towarzyszy, sprawiało, że czas spędzony w niewoli był znaczony godzinami trwogi i zwątpienia. „Twórcy staropolscy - jak stwierdza Renata Ryba poruszali jeszcze jeden dehumanizujący aspekt zjawiska niewoli. Zauważali, że istotą losu człowieka zniewolonego jest niemal zupełny brak nadziei na odmianę na wolność” ${ }^{2}$. Trzeba jednak odnotować, że los jeńca bywał zmienny, podobnie zresztą jak nastroje zależne od wielu czynników; czasem na horyzoncie majaczyła śmierć jako jedyna wyzwolicielka i ostateczny kres „utrapień” więzienia:

\section{》A tym prędzej, jeśliże tych więzów tesknicę W dalsze liche nieszczęście zaprowadzi lata, Tu bez chyby zła Jędza stanie mi za kata ${ }^{33}$.}

$\mathrm{Na}$ ogól jednak jeńcy żyli w stanie permanentnego oczekiwania i nadziei na odmianę. W zależności od okoliczności i od osobistej dyspozycji znosili swój los pogodzeni z rzeczywistością, w poczuciu obowiązku: „Za pociechę naprzod wielce dziękuję i mam w Bogu nadzieję, że wszystkie utrapienia, tak chromotę [kalectwo - M. P.], jako i więzienie, tak jako mężczyźnie przystoi, wytrwam”34.

Zdarza się też, że z biegiem czasu więźniowie zaczynali się przyzwyczajać do swojej niedoli, akceptowali stan zniewolenia, choć było to ściśle związane z polepszeniem ogólnej sytuacji i pozytywnymi widokami na przyszłość. W relacji Rożniatowskiego znajdziemy passus podsumowujący rok niewoli, w którym autor wyraźnie zaznacza, że ten okres dla więźniów okazał się spokojniejszy, bo już się „wmieszkali” w miejsce osadzenia:

\section{》Ostatek roku tego z łaski Bożej zszedł w pokoju i szczęśliwszy, niż}

31 „Trapily nas też mrozy srogie, okrutne, prawie przez wszytką zimę, począwszy w grudniu, ale jednak nausilniej tymi czasy, aż prawie ziemia grzmiała jako śpiża”. Ibidem, s. 125.

32 R. Ryba, Literatura staropolska wobec zjawiska niewoli..., s. 112.

33 A. Rożniatowski, Utwory okolicznościowe..., s. 55.

34 A.A.Witusik, Korespondencja jeńców cecorskich... 
tak rok, a to przeto, iżeśmy od samej Wielkiejnocy wolniejszymi byli od trwóg i niebezpieczeństwa. Więc też i to snać tęsknice ujmowało, żeśmy się już wmieszkali, a niektórym tem więtszej przydawało. Niechże się wola Pańska dzieje dalej; jako inszej nadzieje skutek, tak swoboda nasza w Nim samym została i na miłosierdziu Jego zawisła ${ }^{35}$.

W więzieniu zmienia się również postrzeganie czasu, który upływa w rytm tych samych obrazów rzeczywistości, krzątań, ruchów, rytuałów, powszechnej nudy i dręczącego oczekiwania; dzień zlewa się z dniem, a noc z nocą, czas podlega prawom względności, egzystencja więźnia toczy się w powtarzalnych odsłonach:

\section{1) Mała chwila długi się czas zda [...] noc długa się zda, a drugiem, że się dwie albo trzy złożeły. Drudzy i spać nie mogą, czekając pociechy [...] poczynamy powątpiewać (SN, s. 2I4). \\ [...] i jako najprędzej nas z tego więzienia i zatrzymania moskiew- skiego, w którym się dzień rokiem zda, eliberować raczył; nie trzy- mając już dłużej w tej tęsknicy, nie dając dla ostatniej już prawie desperacyjej i rezolucyjej przychodzić i tego ostatku zdrowia sterać, które się jeszcze kiedy do służb JKM i ojczyźnie zejść może $3^{36}$.}

Co ciekawe, czas otrzymany w nadmiarze, mimo że zorganizowany w rytm więziennego rygoru, mógł zostać też spożytkowany na pracę twórczą, jak się stało w przypadku Sebastiana Petrycego, który w „trudach” więziennych znalazł chwilę na skupienie i pochylenie się nad tekstem Horacego. Była to niewątpliwie forma eskapizmu, oderwania się od „utrapienia” duszy i ciała, wyzwolenie z okowów ${ }^{37}$ i „rozmowa” ze zmarłymi (pamiętamy, że tekst był wtedy postrzegany jako uobecnienie $)^{3^{8}}$, jedyna możliwość, by zachować zdrowy umysł:

\Atoli daliśmy z siebie przykład powolnej cierpliwości, bo jako w Polszcze, co jest w wolności ostatniego, widzimy, takośmy tam doznali, mając zniewolone widzenie, słuchanie i miedzy sobą spólne

35 Polska a Moskwa w pierwszej potowie wieku XVII..., s. 120.

36 J. Budziło, Wojna moskierwska..., s. 173.

37 Zob. G. Trościński, „Wiek naprawdę stracony”. Poezja Sebastiana Petrycego jako świadectwo klęski wyprawy moskiewskiej, „Napis” 2006, seria 12, s. 141-142.

38 Zob. J. Domański, Tekst jako uobecnienie. Szkice z dziejórw myśli o piśmie i książce, Kęty 2002. 
obcowanie odjęte, co jest ostatniego w niewoli. Rozum byśmy byli stracili, gdyby to w naszej woli było szaleć, jako jest milczeć. [...]

W takiej ciasności jako było żyć, co było dobrego czynić? Gdzie nie było miejsca doktorskiej powinności, udałem się do starych nauk i sposobnych do wszelakich w nieszczęściu uciech, i gotowych obojga wspierać życia ${ }^{39}$.

Petrycy miał świadomość, że należy wygospodarować sobie własną przestrzeń, niezależną, która byłaby zdominowana przez umysł i dzieło, a tym samym autonomiczna i odporna na świat zewnętrzny. Pochylanie się nad tekstem w tych warunkach miało charakter medytacyjny. Nieco odmienną, choć w pewnej mierze podobną strategię ucieczki od niedogodności losu w inną przestrzeń przedstawił Zbigniew Morsztyn w utworze List do Imci Pana Aleksandra Mierzeńskiego....

》 Jako więc kiedy w pogańskie krainy

Ciężkie uczynił więzień przenosiny,

Od bisurmańskiej gdzie nieznośne ręki

Ponosi męki

Jeśli snem kiedy powieka zmorzona

Od ciężkiej prace, przecię nieuśpiona

Myśl go przenosi, choć w kajdanach nogi,

W ojczyste progi.

Śni mu się, że już odrzucił okowy,

Że widzi komin, czuje dym domowy $[\ldots]^{40}$

Sen pragnieniowy, a w zasadzie marzenie na jawie („przecię nieuśpiona/ Myśl”), staje się świadomą wizualizacją domu, onirycznym z ducha locus amoenus. Więzień ucieka w obrazy kreślone wyobraźnią i już „nie ma go tu, gdzie jest, a jest tam, gdzie go nie ma"4r. Czy jednak ucieczka w sen-marzenie może wyzwolić? Pytanie pozostaje otwarte. W innym miejscu, w Dumie niewolniczej, autor Emblematów

39 S. Petrycy, Horatius Flaccus w trudach więzienia moskierwskiego, wyd. J. Wójcicki, Warszawa 2006, s. 38-39.

40 Z. Morsztyn, Wybór wierszy, oprac. J. Pelc, Wrocław 1975, s. 365.

41 O śnie u Zbigniewa Morsztyna zob.: K. Mrowcewicz, Trivium poetów polskich epoki baroku: klasycyzm - manieryzm - barok. Studia nad poezja XVII stulecia, Warszawa 2005; M. Pliszka, W onirycznym teatrze. Sen w poezji polskiego baroku, Siedlce 2015. 
w poetyckim sztafażu opisuje ponurą egzystencję więźnia. Przywołajmy kilka fragmentów:

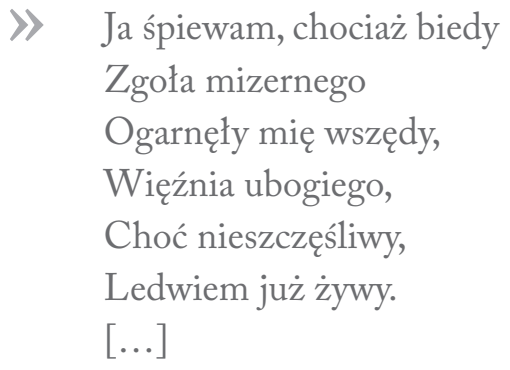

Ja śpiewam, a me siły

Tak długim więżeniem

Już się cale zwątliły,

Żem już prawie cieniem,

Mną, gdy wiatr wieje

Jak trzciną chwieje.

$[\ldots]$

Ja śpiewam, choć o wodzie

I o samym chlebie

Trwać muszę w takim głodzie,

W tak ciężkiej potrzebie,

Patrzę azali,

Kto się użalii ${ }^{2}$.

Morsztyn ujmuje w mowie wiązanej wszystkie niedogodności i nędze egzystencji więźnia, które opisywali diaryści i pamiętnikarze: mizernego niczym cień, niedożywionego, zmęczonego długim żywotem w okowach, z nadwątlonym zdrowiem („Wisi na nitce zdrowie”), na wpół żywego (jest skamieniały jak Niobe, człowiek-trzcina). Autor Muzy domowej do opisu więziennej niedoli wyzyskuje chwyty z repertuaru charakterystycznego dla topiki epicedialnej. Niewątpliwie takie zabiegi podnoszą wielkość cierpienia, a jednocześnie egzystencjalne utrapienia przenoszą w sferę konwencji, mniej wszak tu osobistego głosu i wprost wyrażonego doświadczenia. Morsztyn swój ból wykrzykuje poetyckim rymem w mowie już utrwalonej, do pewnego stopnia skonwencjonalizowanej. Nie zmienia to jednak wymowy utworu ani nie sprawia, że doświadczenie izolacji więziennej jawi się jako 
mniej dotkliwe. Poetycka fraza niesie stwierdzenia uniwersalne, izolacja więzienna jest przekuwana w prawdy powszechne, metaforyzowana, zaś w narracji epickiej, $\mathrm{w}$ diariuszu, pamiętniku, dominuje realistyczne przedstawienie skupione na ukazaniu doświadczenia w sposób jak najbardziej mimetyczny.

Los więźnia toczył się pod dyktando wrogów i oprawców, był rozpięty między udrękami ciała (można wówczas mówić nawet o doświadczeniu cielesnym kaźni, którymi niewątpliwie były doskwierający głód, choroby, zimno, niekiedy zakuwanie w kajdany) a doświadczeniem izolacji niejako przestrzenno-duchowej: od domu, od rodziny, co powodowało dyskomfort psychiczny prowadzący do popadania w stany melancholii, zwątpienia czy też do utraty nadziei.

Za podsumowanie niech posłużą słowa Stanisława Niemojewskiego, w których na pewno odnajdziemy echo niepokojów Montaigne’a, tyle że popartych osobistym doświadczeniem egzystencjalnym:

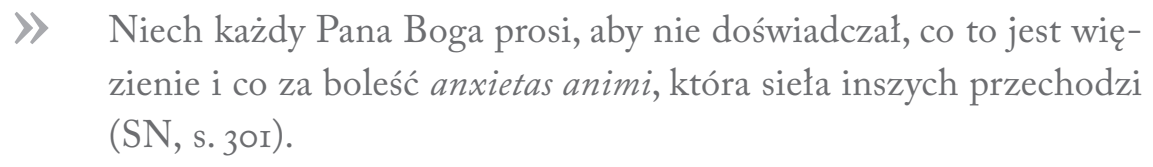

\section{BibliogRAFIA PODMIOTOWA}

Budziło J., Wojna moskierwska wzniecona i prowadzona z okazji fatszywych Dymitrów od 1603 do 1612 r[oku], oprac. J. Byliński, J. Długosz, Wrocław 1995.

Druszkiewicz S.Z., Pamiętniki 1648-1697, oprac. M. Wagner, Siedlce 2001.

Gorczyn P., Thren abo lament żatosny więżniów koronnych do hord tatarskich w roku 1618 zabranych, Mf. 103587, BN.XVII.3.15926.

Kamieński-Dłużyk A., Diariusz więzienia moskierwskiego, miast i miejsc, oprac. A. Kuczyński, B. Polewoj, Z.J. Wójcik, Wrocław 1997, s. 13.

Malewska H., Listy staropolskie z epoki Wazów, Warszawa 1959.

Montaigne M. de, Próby, tłum. T. Żeleński (Boy), oprac. Z. Gierczyński, t. 1-3, Warszawa 1985.

Morsztyn Z., Wybór wierszy, oprac. J. Pelc, Wrocław 1975.

Niemojewski S., Diariusz drogi spisanej i różnych przypadków pociesznych i żatosnych prowadzac córkę Jerzego Mniszka, Maryne, Dymitrowi Iwanowiczowi w roku 1606, wyd. R. Krzywy, Warszawa 2006.

Pamiętniki o Koniecpolskich, wyd. S. Przyłęcki, Lwów 1842.

Petrycy S., Horatius Flaccus w trudach więzienia moskierwskiego, wyd. J. Wójcicki, Warszawa 2006.

Polska a Moskwa w pierwszej potowie wieku XVII. Zbiór materiatów do historii stosunków polsko-rosyjskich za Zygmunta III, wyd. A. Hirschberg, Lwów 1901.

Rękopis Biblioteki im. Raczyńskich w Poznaniu (sygn. 139), BN mf 8919.

Rożniatowski A., Utwory okolicznościowe, oprac. R. Krzywy, Warszawa 2012.

Wieliczko M., Jeniectwo wojenne Polaków w Rosji w latach 1503-1918, Lublin 1998.

Witusik A.A., Korespondencja jeńców cecorskich, „Rocznik Lubelski” 1987-1988, nr 29-30. 


\section{BIBLIOGRAFIA PRZEDMIOTOWA}

Barłowska M., Michata Leona Obuchowicza teksty z moskiewskiej niewoli, „Śląskie Studia Polonistyczne” 2017, nr 2 (10).

Domański J., Tekst jako uobecnienie. Szkice z dziejów myśli o piśmie i książce, Kęty 2002.

Flacelière R., Życie codzienne w Grecji za czasów Peryklesa, tłum. Z. Bobowicz, J. Targalski, Warszawa 1985. Foucault M., Nadzorować i karać. Narodziny więzienia, tłum. T. Komendant, Warszawa 2009.

Kalisz T., Kara pozbawienia wolności na ziemiach polskich od XV do potowy XIX wieku, „Acta Universitatis Wratislaviensis. Przegląd Prawa i”2020, t. 120, nr 2.

Krzywy R., Wstęp, w: S. Niemojewski, Diariusz drogi spisanej i różnych przypadków pociesznych i żatosnych prowadzac córke Jerzego Mniszka, Maryne, Dymitrowi Iwanowiczowi w roku 1606, wyd. R. Krzywy, Warszawa 2006.

Wstęp, w: A. Rożniatowski, Utwory okolicznościowe, oprac. R. Krzywy, Warszawa 2012.

Łoziński W., Prawem i lewem. Obyczaje na czerwonej Rusi w pierwszej potowie XVII wieku, oprac. J. Tazbir, Warszawa 2005.

Mrowcewicz K., Trivium poetów polskich epoki baroku: klasycyzm - manieryzm - barok. Studia nad poezja XVII stulecia, Warszawa 2005.

Pliszka M., W onirycznym teatrze. Sen w poezji polskiego baroku, Siedlce 2015.

Ryba R., Literatura staropolska wobec zjawiska niewoli tatarsko-tureckiej. Studia i szkice, Katowice 2014.

Motyw niewoli tatarsko-tureckiej w poezji poczatku XVII wieku: z perspektywy grzechu, „Napis” 2006, seria 12.

Trościński G., „Wiek naprawdę stracony”. Poezja Sebastiana Petrycego jako świadectwo klęski wyprawy moskierwskiej, „Napis”2006, seria 12.

SŁowA KLUCZE: pamiętnik, diariusz, izolacja, więzienie, XVII wiek

\section{Prison isolation as existential experience in Polish Baroque Literature. SELECTED EXAMPles}

The article focuses on the experience of isolation and evidence thereof in personal document literature (journals, diaries, letters, among others), as well as on the traces of prison experiences in poetic texts (such as by Zbigniew Morsztyn).

Questions posed by the author of the article relate to various aspects of experiencing prison trauma. They concentrate on issues and topics such as: man and fate, nostalgia, resentment, torture, making use of time in isolation (from despair to acts of literary creativity). One subject of special interest to the author is a particular literary diction (verbalising discomforts of isolation), taking shape in the discourse of the self as inmate, as well as the transforming of this extreme experience into a literary image.

KEY wORDs: journal, diary, isolation, prison, seventeenth century 